\title{
Pengembangan Fitur Video Pembelajaran untuk Mendukung Materi Pembelajaran Digital Secara Online pada SMK Miftahul Huda
}

\author{
Imam Solikin \\ Manajemen Informatika, Universitas Bina Darma \\ imamsolikin@binadarma.ac.id
}

\begin{tabular}{l}
\hline \hline Article Info \\
\hline Article history: \\
Received 2020-11-10 \\
Revised 2020-11-28 \\
Accepted 2020-12-03
\end{tabular}

Keyword:

Learning Videos, Digital Materials, Online,

Linear Sequential.

\begin{abstract}
This research is a development from previous research in the form of digital module learning media, the development carried out is in the form of adding features that contain learning videos to support online digital learning materials. This research was conducted at SMK Miftahul Huda which is located on Jalan Lintas Timur Km 124, Tugu Agung Village, Lempuing District, Ogan Komering Ilir Regency. During the Covid 19 pandemic, the teaching and learning process in schools was hampered by the delivery of material, because there were no face-to-face meetings to deliver material. Most of the delivery of material at this time only uses WhatsApp in the form of photos of material, sample questions and exercises, this makes students confused in understanding the content of the material, sample questions and doing their assignments. The method used in the development of the learning video feature to support online digital learning materials at Miftahul Huda Vocational School is a linear sequential model. The solution to overcome the problems faced by SMK Miftahul Huda is to develop learning media in the form of learning video feature applications and digital materials that can be accessed online using a smartphone. The purpose of developing this learning application can make it easier to understand the learning material because in addition to the material files there are learning videos that explain the contents of the material and sample questions. Another convenience that is obtained is that this application can be accessed anywhere at any time and can be studied repeatedly, so as to increase student interest in learning and student learning to the maximum.
\end{abstract}

This is an open access article under the CC-BY-SA license.

\section{Pendahuluan}

Kemajuan teknologi informasi sangat membantu untuk mendukung proses belajaran mengajar dimasa pandemi covid 19. Kemajuan teknologi tersebut bisa digunakan untuk menggantikan proses belajar mengajar tatap muka menjadi proses belajar mengajar secara virtual (online), untuk mengurangi penyebaran covid 19. Pada masa sekarang masih ada beberapa sekolahan yang belum memanfaatkan kemajuan teknologi informasi dalam membantu proses belajar mengajar secara online. Adapun kemajuan teknologi yang ingin dikembangkan untuk membantu proses belajar mengajar secara tatap muka dan mengurangi dampak penyebaran pandemi covid 19, adalah pengembangan fitur video pembelajaran untuk mendukung materi pembelajaran digital secara online. Arah teknologi informasi yang akan dikembangkan harus sesuai dengan tren sekarang ini yaitu berbasis smartphone. Smartphone sekarang bukan hanya digunakan untuk media komunikasi saja tetapi juga digunakan untuk media belajar secara online (virtual). Aplikasi pengembangan fitur video pembelajaran secara online juga harus bisa diakses secara maksimal melalui smartphone. Website responsif merupakan website yang bisa menyesuaikan tampilan layout ukuran viewport dari device yang digunakan mulai dari smartphone, tablet atau komputer screen [1].

Di masa pandemi covid 19 ini proses belajar mengajar pada sekolah banyak yang terhambat dalam penyampaian materi, contoh soal, dan latihan karena tidak ada pertemuan tatap muka untuk menyampaikan materi, contoh soal, dan latihan. 
Penyampaian materi saat ini banyak yang hanya menggunakan WhatsApp dengan mengirim foto dari materi dan contoh soal, hal tersebut membuat siswa menjadi kebingungan dalam memahami materi, contoh soal dan mengerjakan tugasnya. Salah satu sekolahan di Kecamatan Lempuing Kabupaten Ogan Komering Ilir yang juga mengalami permasalahan tersebut adalah SMK Miftahul Huda Tugu Agung.

Solusi untuk mengatasi permasalahan yang dihadapi SMK Miftahul Huda, dengan melakukan pengembangan media pembelajaran berupa sistem pembelajaran yang dilengkapi dengan video pembelajaran dan materi digital secara online yang dapat diakses menggunakan smartphone. Tujuan dari pengembangan sistem pembelajaran ini dapat mempermudah dalam memahami materi pembelajaran karena selain file materi terdapat video pembelajaran yang menjelaskan isi materi dan contoh soal. Kemudahan lain yang didapat adalah aplikasi ini dapat diakses dimanapun kapanpun dan dapat dipelajari berulang-ulang, sehingga bisa meningkatkan minat belajar siswa dan belajar siswa menjadi maksimal.

Adapun penelitian-penelitian yang telah dilakukan sebelumnya penelitian yang menghasilkan media pembelajaran berbasis video CD tutorial [2] memiliki kelebihan secara fitur dimana tampilan video tutorial menarik dan diiringi dengan irama musik. Hasil penelitiannya peserta didik atau siswa dapat belajar dengan mudah mengulang bagian yang dianggap belum jelas. Penelitian video tutorial dalam pembelajaran sistem pengapian di SMK [3], menghasilkan media pembelajaran video tutorial sistem pengapian sepeda motor. Hasil penelitian sebagai alternatif pembelajaran dengan mengubah dari media berupa benda nyata menjadi multimedia berupa video tutorial sistem pengapian sepeda motor. Penelitian lainnya media pembelajaran berbasis video tutorial pada mata kuliah mekanika tanah [4]. Penelitian ini untuk mengetahui tingkat kelayakan media pembelajaran berbasis video tutorial. Beberapa penelitian tersebut [2][3][4], memiliki keterbatasan yakni video tutorial yang dihasilkan bersifat offline sehingga memiliki peluang untuk mengembangkan penelitian berbasis online.

Kemudian penelitian media pembelajaran mobile learning [5] menghasilkan media pembelajaran mobile learning yang dibangun menggunakan application builder appy pie, dan keunggulan dari media pembelajaran ini adalah mudah digunakan oleh siswa dan guru pada mata pelajaran Sistem dan Instalasi Tata Udara. Penelitian media pembelajaran video tutorial berbasis website [6] untuk meningkatkan hasil belajar peserta didik mata pelajaran pemasaran online SMK Negeri Kabupaten Sukoharjo. Penelitian materi digital berbasis web mobile menggunakan Model 4D [7]. Penelitian ini menghasilkan suatu aplikasi berbasis web mobile dengan keunggulan dari aplikasi yaitu dapat diakses menggunakan smartphone. Penelitian fitur notifikasi $e$-modul pada Program Studi Manajemen Informatika [8], hasil penelitian perancangan dapat memudahkan dalam mengakses dan mengupdate materi karena terdapat notifikasi kebaharuan materi. Pengembangan yang dilakukan dari penelitian sebelumnya [7] dan [8] yaitu berupa fitur video pembelajaran, isi dari video pembelajaran tersebut merupakan penjelasan dari materi setiap pertemuan. Beberapa penelitian tersebut maka penelitian kali ini mencoba menerapkan perancangan media pembelajaran secara online pada SMK Miftahul Huda untuk mendukung materi pembelajaran digital selama pandemic Covid 19.

\section{Metode Penelitian}

\section{A. Teknik Pengumpulan Data}

Teknik pengumpulan data merupakan langkah yang paling strategis dalam melakukan penelitian, karena tujuan dari penelitian adalah mendapatkan data untuk menghasilkan informasi yang berguna [9]. Metode penelitian yaitu cara ilmiah dalam mengumpulkan data untuk tujuan dan kegunaan tertentu [10]. Metode pengumpulan data yang digunakan dalam penelitian ini yaitu teknik observasi, teknik interview, dan teknik dokumentasi.

1. Teknik observasi [11],

Observasi yang dilakukan peneliti dengan langsung melihat lingkungan SMK Miftahul Huda.

2. Teknik wawancara [12],

Wawancara dilakukan terhadap Guru SMK Miftahul Huda. Wawancara tersebut berupa, bagaimana proses belajaran mengajar pada SMK di masa pandemi covid 19, media apa saja yang digunakan untuk fasilitas belajar mengajar pada SMK Miftahul Huda dimasa pandemi covid 19, dan permasalahan yang dihadapi dalam proses belajar mengajar pada SMK Miftahul Huda di masa pandemi covid 19.

3. Teknik dokumentasi [13]

Data yang didapat dari teknik dokumentasi pada SMK Miftahul Huda yaitu data RPP, Materi Bahan Ajar, dan video pembelajaran.

\section{B. Metode Pengembangan Sistem}

Metode yang digunakan dalam pengembangan fitur video pembelajaran untuk mendukung meteri pembelajaran digital secara online pada SMK Miftahul Huda adalah linier sequential model [14], adapun tahap-tahapnya adalah analysis, design, coding, testing. Siklus pengembangan sistem tersebut dapat dilihat pada gambar 1 .

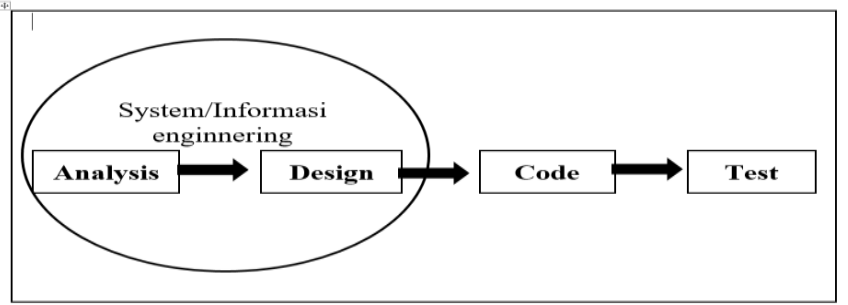

Gambar 1. Metode pengembangan sistem

1) Software requirements analysis,

Untuk melakukan analisa dilakukan pengumpulan data menggunakan teknik observasi, teknik interview, dan 
teknik dokumentasi yang dilakukan pada SMK Miftahul Huda

2) Design,

Proses yang dilakukan pada tahap ini berupa design pengembangan fitur video pembelajaran secara online pada SMK Miftahul Huda menggunakan use case dan flowchart. Design use case [14] implementasi fitur video pembelajaran secara online dapat dilihat pada gambar 2, sedangkan design flowchart [15] implementasi fitur video pembelajaran secara online dapat dilihat pada gambar 3.

3) Code generation,

Pada tahap ini merupakan lanjutan dari tahap desain yang merupakan pengkodingan atau pembuatan program yang menghasilkan video pembelajaran yang dapat diakses secara online.

4) Testing,

Tahap ini merupakan tahap pengujian untuk sistem yang dikembangkan yaitu pengembangan fitur video pembelajaran secara online.

\section{Use Case dan Flowchart}

Penjelasan use case pada gambar 2, untuk masuk ke aplikasi video pembelajaran online, staff tata usaha, guru, dan siswa harus melakukan login terlebih dahulu.

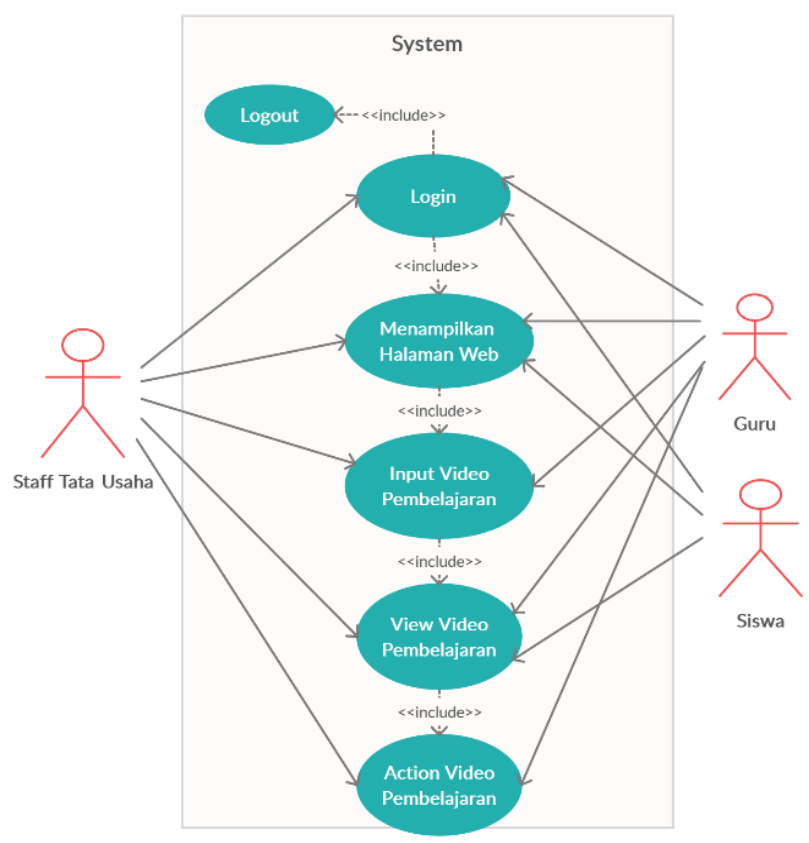

Gambar 2. Use case sistem video pembelajran online

Gambar 2 menunjukkan bahwa guru dan staff tata usaha dapat melakukan aktivitas login, input video pembelajaran, view video pembelajaran, update video pembelajaran, dan delete video pembelajaran. Sedangkan siswa hanya bisa melakukan aktivitas login dan view video pembelajaran.

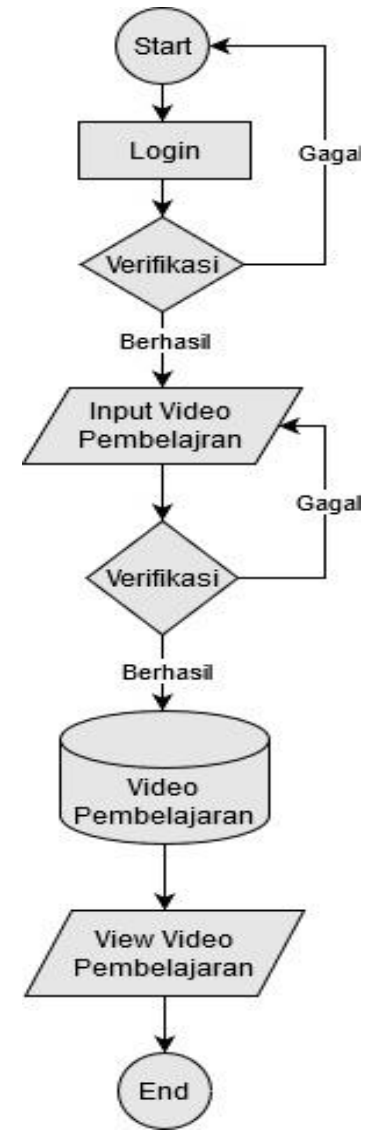

Gambar 3. Flowchart sistem video pembelajran online

Flowchart pada gambar 3, menjelaskan proses aplikasi video pembelajaran, pertama pengguna (user) harus login terlebuh dahulu sesuai dengan hak aksesnya masing masing apabila berhasil lanjut kelangkah selajutnya dan apabila gagal harus mengulang login. Setelah berhasil login user dapat melakukan aktivitas input video pembelajaran apabila gagal harus meng-input ulang dan apabila berhasil di-input maka video pembelajaran tersimpan dalam database, lanjutnya video pembelajaran dapat diakses secara online oleh staff tata usaha, guru, dan siswa

\section{HASil Dan PEMbahasan}

\section{A. Tampilan Implementasi Aplikasi Video Pembelajaran}

Tampilan yang dihasilkan dari proses pengkodingan yaitu aplikasi video pembelajaran pada sekolah SMK Miftahul Huda, yang digunakan untuk media pendukung dari materi pembelajaran. Adapun tampilan-tampilan aplikasi video pembelajaran yang dihasilkan adalah sebagai berikut.

1) Login

Login merupakan tampilan pada gambar 4 menunjukkan yang pertama kali muncul ketika aplikasi dijalankan dan digunakan untuk masuk ke dalam aplikasi dengan hak akses yang berupa e-mail dan password. Pengguna aplikasi adalah admin, guru, dan siswa, dengan hak akses masing-masing untuk menujuk ke tampilan home. 


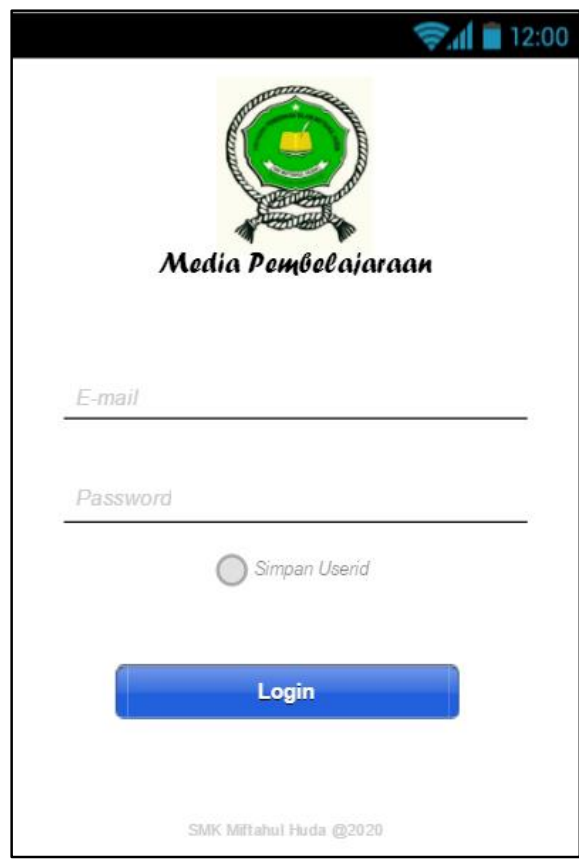

Gambar 4. Login

2) Akun

Akun merupakan tampilan pada gambar 5, berisi alamat tempat tinggal siswa, nomor hp, dan terdapat fasislitas reset password apabila pengguna atau siswa ingin merubah password.

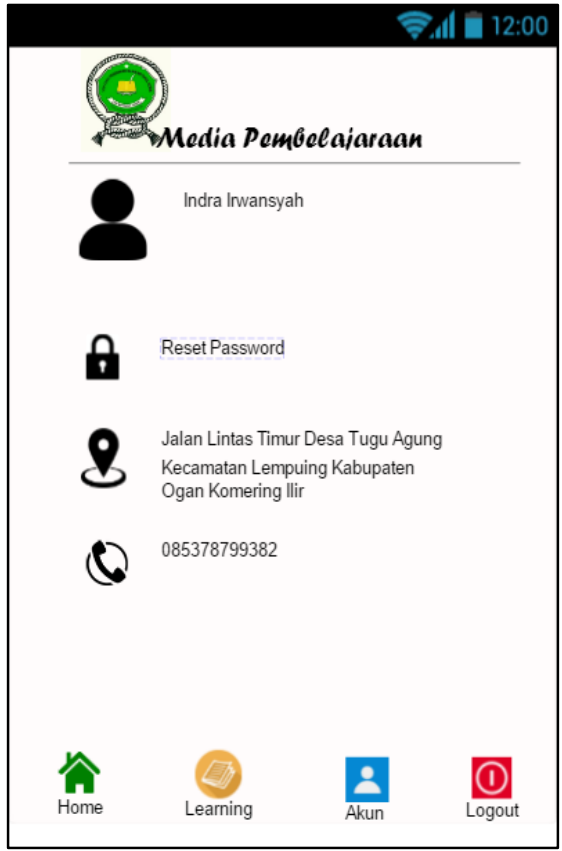

Gambar 5. Akun

3) Mata pelajaran

Mata pelajaran merupakan tampilan pada gambar 6, berisi daftar mata pelajaran yang diikuti siswa pada setiap semesternya. Didalam matapelajaran terdapar materi- materi persetiap pertemuan yang dilengkapi dengan video pembelajaran.

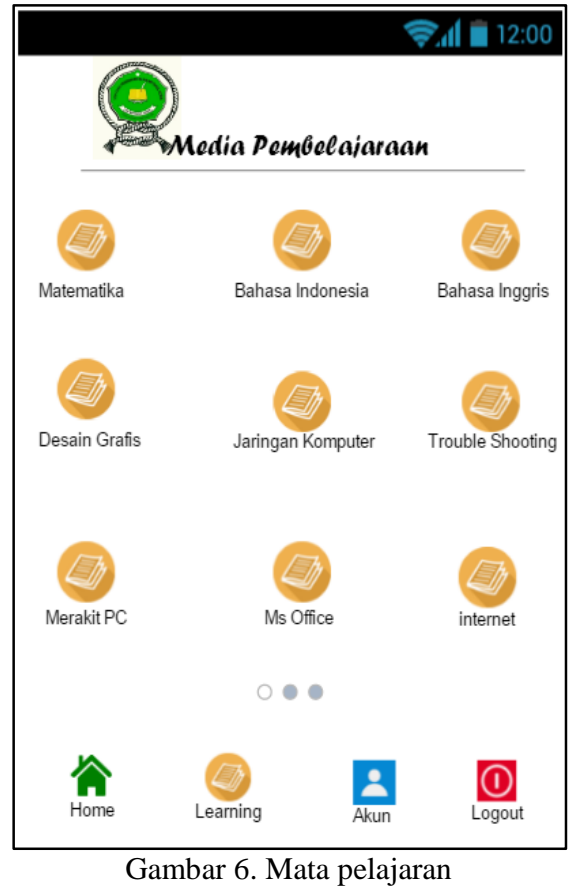

4) Materi pembelajaran

Tampilan materi pembelajaran pada gambar 7, berisi tentang tampilan dari materi-materi setiap pertemuan dari matapelajaran.

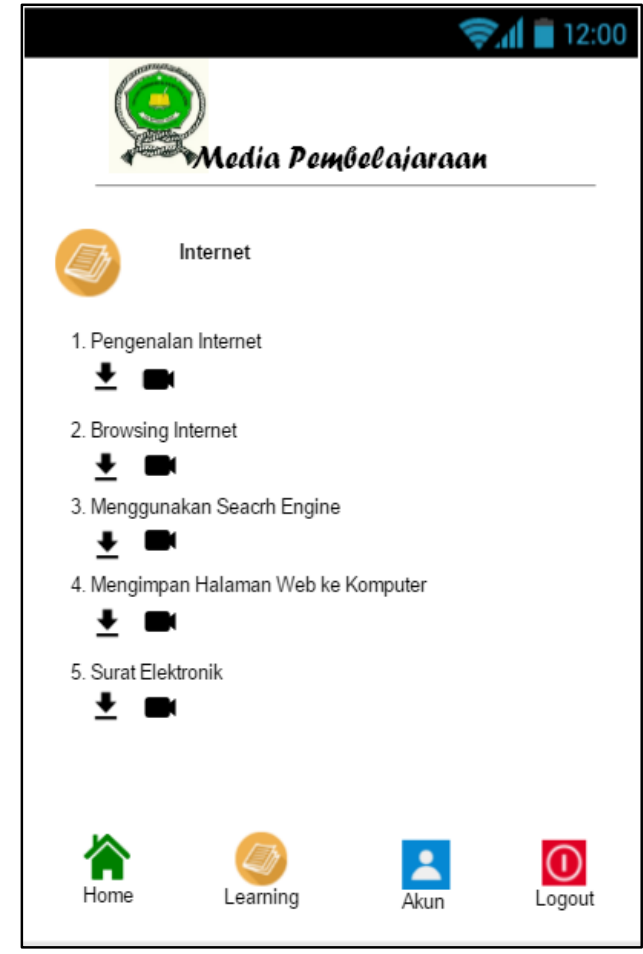

Gambar 7. Materi pembelajaran 
Pada tampilan ini terdapat fasilitas download yang digunakan untuk mendownload file dari materi, kemudian video yang digunakan untuk menampilkan video yang menjelaskan isi dari materi tersebut.

5) Video pembelajaran

Video pembelajaran merupakan tampilan pada gambar 8 , berisi dari video yang menjelaskan isi dari materi pembelajaran.

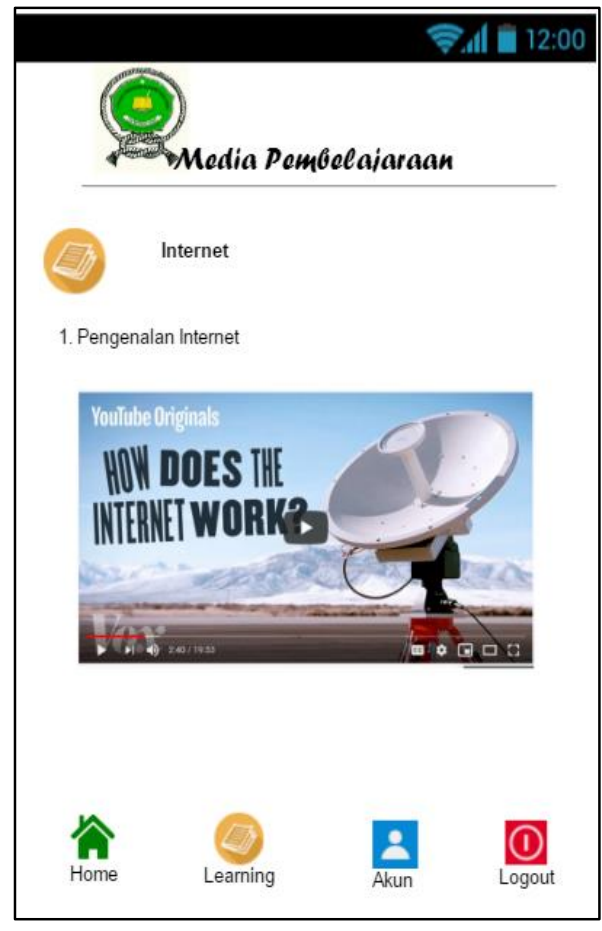

Gambar 8. Video pembelajaran

\section{B. Pengujian Aplikasi Video Pembelajaran}

Pengujian tampilan aplikasi video pembelajaran pada sekolah SMK Miftahul Huda menggunakan pengujian black box, dengan hasil sebagai berikut:

1) Tampilan login merupakan halaman yang tampil pertama kali ketika aplikasi dijalankan, hasil yang didapat dari pengujian (tidak error).

2) Tampilan akun yaitu berisi identitas siswa dan terdapat fasilitas reset password, hasil yang didapat dari pengujian (tidak error).

3) Tampilan mata pelajaran merupakan tampilan dari daftar mata pelajaran setiap semesternya, hasil yang didapat dari pengujian (tidak error).

4) Tampilan materi pembelajaran yaitu berisi materi pembelajaran setiap yang dibagi setiap pertemuan, hasil yang didapat dari pengujian (tidak error).

5) Tampilan video pembelajaran yaitu berisi video pembelajaran yang menjelaskan isi dari materi setiap pertemuan, hasil yang didapat dari pengujian (tidak error).

\section{KESIMPULAN}

Hasil dari penelitian ini berupa aplikasi video pembelajaran pada sekolahan SMK Miftahul Huda, untuk mendukung materi pembelajaran. Setiap video pembelajaran berisi tentang penjelasan dari materi setiap pertemuan. Aplikasi video pembelajaran ini dikembangkan untuk mempermudah guru dalam menyampaikan materi dan mempermudah siswa dalam mempelajari dan memahami isi dari materi. Untuk penelitian selanjutnya agar fitur-fiturnya dapat mengembangkan seperti fitur forum diskusi dan fitur soal latihan.

\section{DAFTAR PUSTAKA}

[1] N. Hasyim, I. R. Mutiaz, and A. Agus Sachari, "Perancangan Desain Apikasi Buku Digital (E-Book) dengan Objek Masjid Agung Demak," J. Techno. com, vol. 13, no. 3, pp. 158-167, 2014

[2] R. H. Wirasasmita and Y. K. Putra, "Pengembangan media pembelajaran video tutorial interaktif menggunakan aplikasi camtasia studio dan macromedia flash," Edumatic J. Pendidik. Inform., vol. 1, no. 2, pp. 35-43, 2018.

[3] A. Y. Utomo and D. Ratnawati, "Pengembangan Video Tutorial dalam Pembelajaran Sistem Pengapian di SMK," TAMAN VOKASI, vol. 6, no. 1, pp. 68-76, 2018.

[4] A. Efendi, S. Sumarni, and A. Efendi, "Pengembangan Media Pembelajaran Berbasis Video Tutorial Pada Mata Kuliah Mekanika Tanah," Indones. J. Civ. Eng. Educ., vol. 1, no. 1, 2015.

[5] R. A. Hafidz, K. Sumardi, and M. Komaro, "Desain dan Pembuatan Media Pembelajaran Mobile Learning pada Mata Pelajaran Sistem dan Instalasi Tata Udara," J. Mech. Eng. Educ., vol. 6, no. 1, pp. 71-79, 2019.

[6] D. H. Kusuma, T. Martono, and D. K. Wardani, "Developing WebBased Tutorial Video Learning Media to Improve Students Online Marketing Learning Outcome at Smk Negeri Sukoharjo," BISE J. Pendidik. Bisnis dan Ekon., vol. 4, no. 1.

[7] I. Solikin and R. Amalia, "Materi Digital Berbasis Web Mobile Menggunakan Model 4D," Sist. J. Sist. Inf., vol. 8, no. 3, pp. 321328, 2019.

[8] I. Solikin, "Pengembangan Fitur Notifikasi E-Modul Pada Program Studi Manajemen Informatika," Simetris J. Tek. Mesin, Elektro dan Ilmu Komput., vol. 10, no. 1, pp. 189-196, 2019.

[9] S. Sugiyono, "Metode penelitian kuantitatif dan kualitatif dan R\&D.” Alfabeta Bandung, 2010.

[10] M. P. K. Sugiyono, "Cara Mudah Menyusun: Skripsi." Tesis dan Disertasi, Bandung: Alfabeta, 2014.

[11] H. Hasanah, "TEKNIK-TEKNIK OBSERVASI (Sebuah Alternatif Metode Pengumpulan Data Kualitatif Ilmu-ilmu Sosial)," AtTaqaddum, vol. 8, no. 1, pp. 21-46, 2017.

[12] H. Herdiansyah, "Wawancara, observasi, dan focus groups: Sebagai instrumen penggalian data kualitatif," Jakarta PT. Raja Graf. Persada, 2013.

[13] I. Gunawan, "Metode penelitian kualitatif," Jakarta Bumi Aksara, 2013.

[14] A. Gemino and D. Parker, "Use case diagrams in support of use case modeling: Deriving understanding from the picture," $J$. Database Manag., vol. 20, no. 1, pp. 1-24, 2009.

[15] N. Ensmenger, "The multiple meanings of a flowchart," Inf. Cult., vol. 51, no. 3, pp. 321-351, 2016. 